\title{
Review \\ Epigenetic Control of Infant B Cell Precursor Acute Lymphoblastic Leukemia
}

\author{
Oriol de Barrios * and Maribel Parra *
}

Citation: de Barrios, O.; Parra, M. Epigenetic Control of Infant B Cell Precursor Acute Lymphoblastic Leukemia. Int. J. Mol. Sci. 2021, 22, 3127. https://doi.org/10.3390/ ijms22063127

Academic Editor: Markus Proft

Received: 14 February 2021

Accepted: 17 March 2021

Published: 18 March 2021

Publisher's Note: MDPI stays neutral with regard to jurisdictional claims in published maps and institutional affiliations.

Copyright: (c) 2021 by the authors. Licensee MDPI, Basel, Switzerland. This article is an open access article distributed under the terms and conditions of the Creative Commons Attribution (CC BY) license (https:// creativecommons.org/licenses/by/ $4.0 /)$.
Lymphocyte Development and Disease Group, Josep Carreras Leukaemia Research Institute (IJC), Ctra. de Can Ruti, Camí de les Escoles s/n, 08916 Barcelona, Spain

* Correspondence: odebarrios@carrerasresearch.org (O.d.B.); mparra@carrerasresearch.org (M.P.); Tel.: +34-93-557-28-00 (ext. 4222) (O.d.B.); +34-93-557-28-00 (ext. 4210) (M.P.)

\begin{abstract}
B-cell precursor acute lymphoblastic leukemia (BCP-ALL) is a highly aggressive malignancy, with poorer prognosis in infants than in adults. A genetic signature has been associated with this outcome but, remarkably, leukemogenesis is commonly triggered by genetic alterations of embryonic origin that involve the deregulation of chromatin remodelers. This review considers in depth how the alteration of epigenetic profiles (at DNA and histone levels) induces an aberrant phenotype in B lymphocyte progenitors by modulating the oncogenic drivers and tumor suppressors involved in key cancer hallmarks. DNA methylation patterns have been widely studied in BCP-ALL and their correlation with survival has been established. However, the effect of methylation on histone residues can be very different. For instance, methyltransferase KMT2A gene participates in chromosomal rearrangements with several partners, imposing an altered pattern of methylated H3K4 and H3K79 residues, enhancing oncogene promoter activation, and conferring a worse outcome on affected infants. In parallel, acetylation processes provide an additional layer of epigenetic regulation and can alter the chromatin conformation, enabling the binding of regulatory factors. Therefore, an integrated knowledge of all epigenetic disorders is essential to understand the molecular basis of BCP-ALL and to identify novel entry points that can be exploited to improve therapeutic options and disease prognosis.
\end{abstract}

Keywords: epigenetics; acute lymphoblastic leukemia; B lymphocytes

\section{Introduction}

Acute lymphoblastic leukemia (ALL) derived from B lymphocytes has the highest annual incidence of all diagnosed childhood cancers in developed countries [1]. This type of leukemia can be subdivided into several subtypes, depending on the differentiation stage at which B lymphocytes acquire malignant properties that impair their proper development $[2,3]$. Recent research has allowed the implementation of patient stratification and more personalized therapies, which has improved the 5-year overall survival rate to as much as 90\% [4]. However, the outcome of B-cell precursor ALL (BCP-ALL) in infants (younger than one year of age) is much more aggressive than in older children and adults, severely compromising their survival chances. In fact, a specific subgroup of patients harboring chromosomal rearrangements at the KMT2A gene (also known as $M L L$, mixed-lineage leukemia) is of special interest to basic researchers and clinicians, given its critically poor associated prognosis and elevated relapse frequency [5,6].

The gene expression profiling of infants diagnosed with BCP-ALL has revealed the existence of a genetic signature that determines the degree of aggressiveness and outcome of this malignancy [7,8]. Seminal work from Pieters' laboratory in 2010 reported that the expression of the HOX homeobox gene family (HOXA3, HOXA5, HOXA7, HOXA9, and HOXA10) is correlated with a favorable prognosis [7]. HOXA9 is frequently co-expressed with homeobox transcription factor MEIS1 [9,10], and the combined downregulation of both genes prevents leukemic cells from proliferating uncontrollably [11]. In addition, 
the tyrosine kinase receptor FLT3 has become a widely used marker of prognosis and a potential therapeutic target [12-14], although FLT3 inhibitors have not yet succeeded in improving disease outcomes [15]. A recent genome-wide analysis of a large cohort of BCP-ALL infants has identified a novel genetic signature that can help predict disease progression and patient outcomes [8]. Therefore, patients with elevated expression of CDK inhibitors (such as p21 and p16), TGFB1 or SMAD and reduced levels of genes involved in DNA integrity preservation and DNA repair (e.g., CHEK1, ATM, and BRCA1) are classified among the poor-prognosis subtypes of BCP-ALL [8].

The expression of these and other genes that act as essential drivers of BCP-ALL is driven by several mechanisms. The multistep process by which the immune system is built up during embryogenesis requires strict control during the B lymphocyte differentiation process [16]. However, this strict equilibrium can be deregulated by genetic alterations (e.g., fusion genes generated by chromosomal translocations or hyperdiploidy) that take place before birth, leading to an aberrant differentiation stage considered to be a pre-leukemic clone [3,6]. Although a variety of hypotheses have been proposed [3,17], it is believed that a prenatal secondary hit completes the onset of an overt BCP-ALL. Some genes involved in the initial genetic alterations (such as KMT2A) exert a key function in altering target gene expression by epigenetic remodeling and regulate hematopoietic system development in mammals $[18,19]$. In addition, most primary and secondary hits involve the deregulation of epigenetic mechanisms, either by directly modifying DNA or by specifically altering chromatin epigenetic marks. It must be noted that the aberrant behavior of these genes, involved in epigenetic regulation and chromatin remodeling, is more frequent in infant BCP-ALL than in adults, especially in recurrent cases [20] Here, we review the most relevant epigenetic mechanisms that aberrantly alter gene expression in BCP-ALL.

\section{Epigenetic Alterations That Affect Gene Expression in BCP-ALL}

\subsection{Role of Epigenetic Modifications in Cancer}

Epigenetics refers to the mechanisms that modify gene expression in a reversible way, without introducing permanent alterations in the DNA sequence itself [21]. However, an inappropriate expression of specific genes due epigenetic mutations can be inherited, even though the primary coding sequence remains unaltered [22]. The most common epigenetic marks consist of covalent modifications that can affect DNA nucleotides and histones [21]. These mechanisms are frequently found to be aberrantly deregulated in several types of cancer [22,23]. The commonest types of epigenetic alterations are DNA methylation in cytosine residues, which are associated with gene repression, and histone modifications, which mainly occur through the methylation, acetylation, or ubiquitination of specific residues that have distinct effects on gene expression depending on the residue and genomic region affected [21,22]. The ways by which epigenetic modifications influence progression of BCP-ALL are summarized in Table 1 and described in further detail in the following sections.

Table 1. Common epigenetic histone modifications in B-cell precursor acute lymphoblastic leukemia (BCP-ALL).

\begin{tabular}{|c|c|c|c|c|}
\hline Histone Mark & Regulators & $\begin{array}{l}\text { Effect on Chromatin } \\
\text { Conformation }\end{array}$ & $\begin{array}{c}\text { Alteration of Gene } \\
\text { Expression and Biological } \\
\text { Processes }\end{array}$ & References \\
\hline \multicolumn{5}{|c|}{ Histone methylation } \\
\hline H3K4me3 & $\begin{array}{l}\text { KMT2A chromosomal } \\
\text { rearrangements } \\
\text { Cofactors: WDR5, } \\
\text { RbBP5, ASHL2, } \\
\text { DPY-30, Menin } \\
\text { PAF1 and E2/E3 } \\
\text { complexes }\end{array}$ & $\begin{array}{l}\text { Transcriptionally active } \\
\text { chromatin, that can } \\
\text { turn into repressive } \\
\text { state, depending on } \\
\text { other marks }\end{array}$ & $\begin{array}{c}\text { Regulation of proper B } \\
\text { lymphocyte development } \\
\text { Oncogenic drivers, such as } \\
\text { FLT3 } \\
\text { It can activate IKZF1 gene }\end{array}$ & [24-34] \\
\hline
\end{tabular}


Table 1. Cont.

\begin{tabular}{|c|c|c|c|c|}
\hline Histone Mark & Regulators & $\begin{array}{l}\text { Effect on Chromatin } \\
\text { Conformation }\end{array}$ & $\begin{array}{c}\text { Alteration of Gene } \\
\text { Expression and Biological } \\
\text { Processes }\end{array}$ & References \\
\hline \multicolumn{5}{|c|}{ Histone methylation } \\
\hline H3K79me3 & $\begin{array}{c}\text { Members of super } \\
\text { elongation complex } \\
\text { (SEC), such as AF4, } \\
\text { AF9 or ENL } \\
\text { DOT1L, NSD1, CARM1 } \\
\text { PAF1 and E2/E3 } \\
\text { complexes }\end{array}$ & $\begin{array}{l}\text { Increased chromatin } \\
\text { accessibility, allows } \\
\text { binding of transcription } \\
\text { factors to promoter } \\
\text { regions }\end{array}$ & $\begin{array}{l}\text { Negative outcome markers: } \\
\text { CPEB2, MBNL1, MCL1, } \\
\text { RUNX1, RUNX2, ZEB2 }\end{array}$ & {$[29,35-41]$} \\
\hline H3K9me3 & IKZF1, SIRT1 & $\begin{array}{l}\text { Repressive chromatin } \\
\text { state }\end{array}$ & $\begin{array}{l}\text { Repression of genes involved } \\
\text { in cell cycle progression } \\
(C D C 2, C D C 7)\end{array}$ & {$[40,42-44]$} \\
\hline H3K36me2/3 & Catalyzed by NSD2 & $\begin{array}{l}\text { Present at bodies of } \\
\text { transcriptionally active } \\
\text { genes, impairing } \\
\text { aberrant transcriptional } \\
\text { initiation }\end{array}$ & $\begin{array}{c}\text { This mark impairs aberrant } \\
\text { leukemogenic activity. NSD2 } \\
\text { mutation triggers cell } \\
\text { proliferation }\end{array}$ & [45-49] \\
\hline H3K27me3 & $\begin{array}{l}\text { EZH2, IKZF1, NuRD } \\
\text { repressive complex } \\
\text { (including HDAC1, } \\
\text { HDAC2 and MI-2) }\end{array}$ & $\begin{array}{l}\text { Close chromatin } \\
\text { conformation }\end{array}$ & $\begin{array}{l}\text { Tumor suppressor function, } \\
\text { preventing cell cycle } \\
\text { progression }\end{array}$ & {$[43-45,50,51]$} \\
\hline H4R3sme2 & PRMT5 & $\begin{array}{l}\text { Closed chromatin } \\
\text { conformation at } \\
\text { promoter regions }\end{array}$ & $\begin{array}{c}\text { Repression of genes involved } \\
\text { in proper B cell differentiation } \\
\text { and apoptosis (like CLC and } \\
\text { CTSB) }\end{array}$ & [52-54] \\
\hline \multicolumn{5}{|c|}{ Histone acetylation } \\
\hline H3К27ac & $\begin{array}{l}\text { EZH2 loss-of-function, } \\
\text { EP300, KMT2A-AF4 } \\
\text { fusion protein }\end{array}$ & $\begin{array}{l}\text { Increased chromatin } \\
\text { accessibility in } \\
\text { enhancer regions, } \\
\text { recruiting CTCF, GR } \\
\text { and PU.1 factors }\end{array}$ & $\begin{array}{l}\text { Induction of BIM target gene, } \\
\text { marker of glucocorticoid } \\
\text { sensitivity. } \\
\text { Activation of BCL2 } \\
\text { antiapoptotic gene and } \\
\text { oncogene FLT3 }\end{array}$ & {$[33,45,55,56]$} \\
\hline $\begin{array}{l}\text { H3K9ac and } \\
\text { H4K16ac }\end{array}$ & $\begin{array}{l}\text { KMT2A-AF4 fusion } \\
\text { protein, in association } \\
\text { with MOF }\end{array}$ & $\begin{array}{l}\text { Active marks on } \\
\text { promoter regions, } \\
\text { allowed by } \\
\text { hypomethylation } \\
\text { pattern at enhancer } \\
\text { regions }\end{array}$ & $\begin{array}{l}\text { Activation of } B C L 2 \\
\text { antiapoptotic gene }\end{array}$ & [56-59] \\
\hline $\begin{array}{c}\text { Global H3 and H4 } \\
\text { acetylation loss }\end{array}$ & $\begin{array}{l}\text { KATs (such as } \\
\text { CREBBP), HDACs and } \\
\text { fusion proteins derived } \\
\text { from genetic alterations } \\
\text { (SLC12A6-NUTM1 or } \\
\text { ZNF384-EP300) }\end{array}$ & $\begin{array}{l}\text { Chromatin silencing } \\
\text { through the imposition } \\
\text { of a repressive state }\end{array}$ & $\begin{array}{l}\text { Poor outcome, associated to } \\
\text { loss of H4 acetylation } \\
\text { Blockade of BIM } \\
\text { Prednisolone treatment } \\
\text { resistance in murine models } \\
\text { with deficit of H3 acetylation } \\
\text { (impairing Rgs16 or Dusp10 } \\
\text { induction) }\end{array}$ & {$[58,60-68]$} \\
\hline \multicolumn{5}{|c|}{ Histone ubiquitination } \\
\hline H2BK120ub & $\begin{array}{l}\text { BRE1 protein complex } \\
\text { (including WAC and } \\
\text { RNF20) }\end{array}$ & $\begin{array}{l}\text { Promotes } \\
\text { transcriptional } \\
\text { elongation by } \\
\text { facilitating H3 } \\
\text { methylation }\end{array}$ & $\begin{array}{l}\text { Presence of } \mathrm{H} 2 \mathrm{BK} 120 \mathrm{ub} \\
\text { residues mediates KMT2A and } \\
\text { DOT1L activity, maintaining } \\
\text { BCP-ALL progression }\end{array}$ & [69-71] \\
\hline
\end{tabular}




\subsection{Histone Methylation Pattern Alterations}

The genetic alterations that drive the onset of childhood leukemia usually involve genes that alter the methylation pattern of specific histones. The most common alterations are detailed below.

\subsubsection{Histone 3 Lysine 4 (H3K4) and Lysine 79 (H3K79) Methylation}

The translocation of long arm (q) of chromosome 11 at distant genome locations usually constitutes an initial pre-leukemic hit in BCP-ALL, which occurs during embryonic development [24,72]. This translocation dramatically alters the pattern of histone methylation in the affected cells, since it involves the KMT2A gene (located in band 11q23), which harbors methyltransferase activity at the histone 3 lysine 4 (H3K4) residue with the capacity to transcriptionally activate gene targets during normal development, by increasing the levels of trimethylated H3K4 (H3K4me3) [24]. This is facilitated by a catalytic SET domain with an ancestral origin, which methylates lysine residues on histones. For this to function, KMT2A requires the cooperation of other cofactors, such as WDR5, RbBP5, ASH2L, and DPY-30 [25,26], to acquire methyltransferase activity. For instance, the absence of WDR5 prevents H3K4 from being methylated [73,74]. Consequently, the strategy of blocking KMT2A-WDR5 association is a promising approach in terms of KMT2A-translocated ALL treatment [75]. Other studies have ruled out the possibility that WDR5 could have a pivotal role, attributing instead a key function to the heterodimer RbBP5-ASH2L as the minimal unit required to conserve KMT2A catalytic activity [76].

The KMT2A protein can function as a transcriptional activator or repressor. This dual role depends on a specific region built up of homeodomains PHD1-4 and an adjacent bromodomain (BD). This structure determines KMT2A protein stability and confers plasticity to its transcriptional activity $[77,78]$. However, point mutations that disrupt the correct formation of this protein region can prevent KMT2A from binding to the BMI1 repressor complex, restricting its activity to gene induction. The outcome of BCP-ALL patients (including infants) with this alteration is poor compared with that of patients with an intact PHD1-4/BD structure [27].

Chromosomal rearrangement of KMT2A generates aberrant fusion proteins with other factors, leading to the modification of their transcriptional activity or resulting in alterations of its own mechanisms. Although more than 70 translocation partners for KMT2A have been reported, four of them (AF4, AF9, AF10, and ENL, located on chromosomes 4, 9, 10, and 19, respectively) account for more than $90 \%$ of infant ALL cases [27,28]. When the KMT2A gene fuses with any of these partners, its methyltransferase activity is affected, which leads to aberrantly altered chromatin states, resulting in a deregulated expression of specific genes that require strict regulation for the proper and controlled development of $B$ lymphocytes $[18,79]$.

The alteration of methyltransferase activity of KMT2A upon genome rearrangement combines with an enhanced ability to recruit chromatin remodelers, incorporated through its new fusion partners, such as AF4. Remarkably, AF4, AF9, AF10, and ENL partners belong to the super elongation complex (SEC) [35,36], together with other methyltransferases such as DOT1L, NSD1, and CARM1 [37]. These enzymes impose histone methylation marks that facilitate an open conformation of chromatin, thereby enhancing gene transcription. The main modifications introduced by SEC proteins are H3K36me2/3, H3K79me2/3, H3R17me2a, and H4K20me1 [37,38]. An aberrantly increased H3K79me3 mark is one of the main hallmarks of KMT2A-rearranged BCP-ALL, a process occurring through the altered activity of the DOT1L enzyme, which is recruited to proximal transcribed regions of active genes $[28,80,81]$. The increase of H3K79me2/3 levels caused by DOT1L involves the downregulation of monomethylated H3K79 residues [81] and a biased proportion of H3K4me3:H3K79me3 levels towards the latter [82]. This conversion is correlated with a dynamic change from low to high levels of gene transcription. In addition, DOT1L recruitment prompts the enrichment in H3K79me marks located at intergenic sequences, which act as enhancers that induce large distance-located promoter regions [81]. It is 
worth mentioning that the altered function of methylating enzymes like DOT1L or NSD2 in BCP-ALL does not lie on an altered protein expression, rather than in a differential binding affinity with their partners, as a result of genomic rearrangements that give birth to aberrant fusion proteins like KMT2A-AF4.

The general pattern of regions bound by KMT2A-AF4 in BCP-ALL cells is characterized by narrow $\mathrm{H} 3 \mathrm{~K} 79 \mathrm{me} 2 / 3$ and $\mathrm{H} 3 \mathrm{~K} 36 \mathrm{me} 3$ picks at gene promoter and enhancers. However, a small but significant proportion of genes show KMT2A-AF4 spreading through the gene body. This subset of genes includes some prognosis markers, like CPEB2, MBNL1, RUNX2, and ZEB2, and is characterized by elevated levels of H3K79me2/3 marks, to the detriment of H3K36me3, indicating greater DOT1L activity in these regions [39]. Among other activities, DOT1L represses SIRT1 histone deacetylase, which enriches chromatin with repressive marks, such as $\mathrm{H} 3 \mathrm{~K} 9 \mathrm{me} 3$, thereby boosting the presence of active enhancer region marks, like H3K27ac [40,42]. Consequently, the methylation of H3K79 residue mediated by DOT1L, combined with SIRT1 inhibition, involves increased chromatin decoration with active, rather than repressive, marks [40]. This increased chromatin accessibility provides a great opportunity for the binding of transcription factors, thereby activating the enhancer function, and increasing the frequency of the interaction with the target promoter. ELF1 is one of the transcription factors whose binding frequency increases when the H3K79me2/3 mark is enriched [40].

In a positive feedback loop, the KMT2A-AF4 fusion protein activates a single member of the SEC, the P-TEFb kinase, which triggers the activity of promoter-arrested RNA polymerase II, and ultimately alters the pattern of the ALL transcriptional profile [38]. In parallel, the PAF1 complex, which is associated with RNA polymerase II, and monitors H3K4 and H3K79 methylation through the involvement of the ubiquitin ligase complex E2/E3 [27,29]. However, the presence of homeobox gene IRX1 impairs the ability of the KMT2A-AF4 fusion protein to bind endogenous cofactors, such as the SEC, and limits the potential recognition of H3K79me3 signatures. In consequence, IRX1 overexpression blocks the induction of leukemogenic drivers such as MEIS1 [83]. Intriguingly, IRX1 has an opposite oncogenic role, by maintaining a quiescent stem-cell state through the enhanced expression of HOXB4 and EGR family members, which increases the incidence of relapse in infants with high levels of IRX1 expression [83,84].

The hypermethylation of CpG islands (CGIs) at promoter regions is usually associated with inactive chromatin, whereas histone methylation may have an opposite effect. For instance, $\mathrm{H} 3 \mathrm{~K} 4 \mathrm{me} 3$ and $\mathrm{H} 3 \mathrm{~K} 79 \mathrm{me} 2 / 3$ are associated with unmethylated promoters, which facilitates gene transcription [41]. KMT2A-fusion proteins generally bind to regions of unmethylated $\mathrm{CpG}$ islands ( $\mathrm{uCpGs)}$ ), and their recruitment to these areas is controlled by other cofactors such as Menin/LEDGF or PAF1 complex [30-32]. Studies from Thomas Milne's laboratory have demonstrated a close coincidence between KMT2A-AF4 and Menin cofactor binding sites, rather than with PAF1 complex, in poor-prognosis BCP-ALL infants [39]. Given the difficulties of trying to directly target KMT2A-AF4, these studies point to Menin as a suitable cofactor for targeting with novel therapeutic strategies. In fact, several compounds (e.g., MI-2 and MI-538) with the ability to interfere with KMT2AMenin binding have been developed, offering a promising strategy for preventing KMT2A binding to specific genomic sites and for activating its direct targets [85].

\subsubsection{Histone 3 Lysine 27 (H3K27) Methylation}

Lysine 27 at histone 3 (H3K27) is an important location for epigenetic regulation. Its strict modulation at enhancer regions may determine the expression of distant promoters. Trimethylation of this specific residue induces a close chromatin conformation, as is very typical in lymphomas, and which is mediated by gain-of-function of Polycomb member EZH2 [50]. However, there is a converse H3K27me3 pattern in BCP-ALL, with decreased methylation and an increased proportion of unmodified or acetylated residues, since EZH2 usually displays loss-of-function mutations in this malignancy [45]. Given the relevance of the H3K27 mark, high-resolution chromosome conformation capture (Hi-C) data have 
provided insight into the mechanisms underlying gene expression in B lymphocytes [86]. An example of this is the regulation of FLT3, an oncogenic driver of BCP ALL [12]. Hi-C data revealed the activated expression of the FLT3 gene in patients with a specific deletion in chromosome 13 (13q12.2). This deletion facilitates increased interactions between H3K4me3 marks at the FLT3 promoter and the H3K27ac activation marks, which are located at an enhancer element within the gene body of the PAN3 gene [33].

Likewise, the importance of H3K27ac marks in determining chromatin accessibility to enhancer regions can help predict how BCP-ALL patients will respond to standard established glucocorticoid therapy. The enrichment in H3K27ac marks within enhancer regions yields an open chromatin conformation and facilitates the recruitment of CTCF transcription factor in cooperation with the glucocorticoid receptor (GR), which induces target genes such as BIM [55]. Accordingly, the BIM enhancer region was found to be demethylated in ALL glucocorticoid-sensitive cells, partially through the recruitment of PU.1, which enables the increased acetylation of H3K27 residue [87]. As a consequence, infants with high levels of H3K27ac enhancer marks respond positively to dexamethasone treatment, whereas those with a low level of enrichment of this epigenetic mark are resistant to the therapy [55].

The importance of epigenetic regulation of the H3K27 residue at distinct regulatory regions of BCP-ALL regulators is shown in Figure 1.

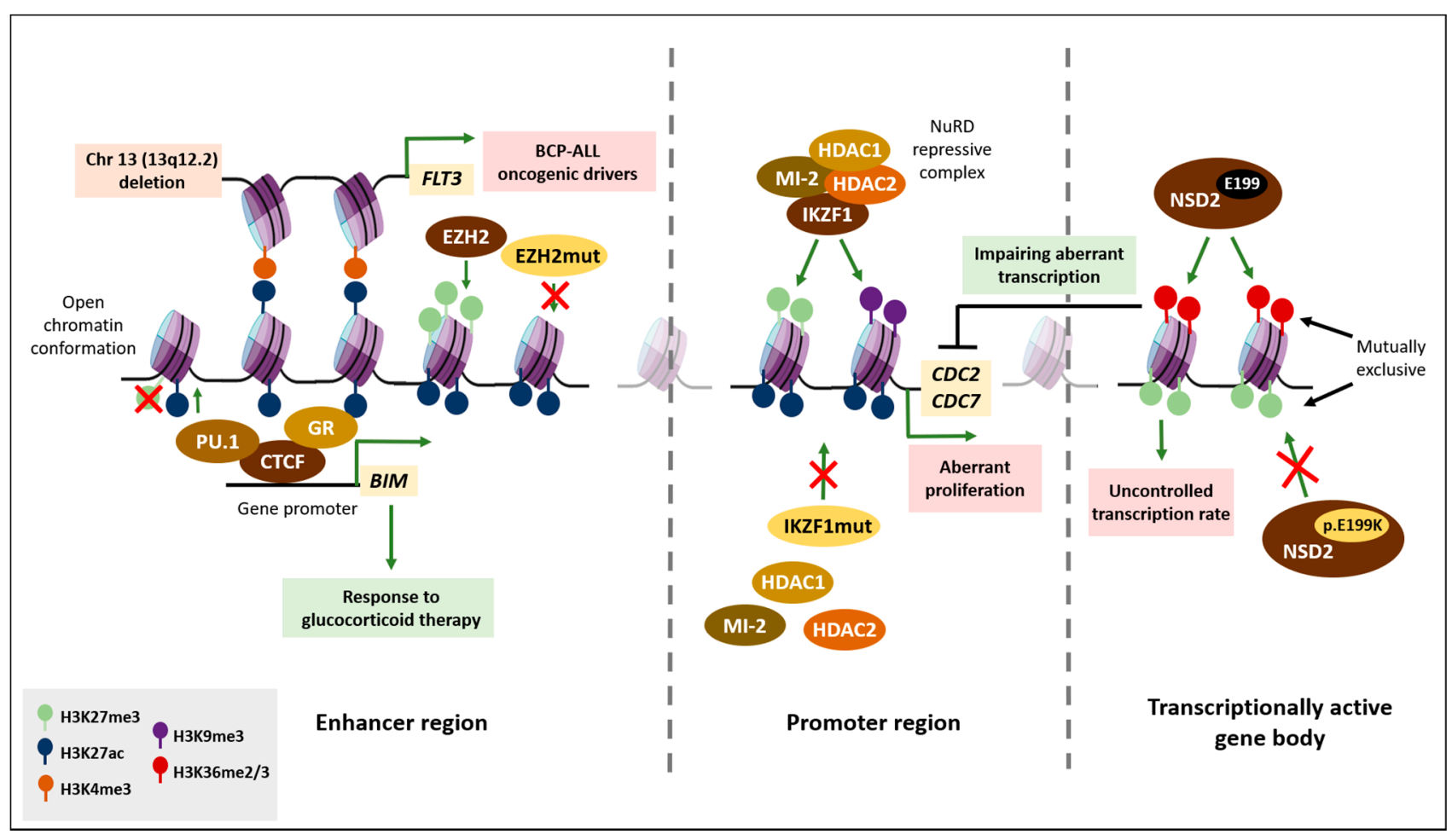

Figure 1. Dual effects of epigenetic regulation of H3K27 in BCP-ALL. Schematic picture of how epigenetic alterations of the H3K27 residue affect gene regulation and key biological processes that guide the progression of BCP-ALL. Green arrows indicate activation; red lines and crosses indicate repression. Black line indicates control of uncontrolled transcription rate. Green squares indicate biological processes that improve BCP-ALL outcome; red squares indicate processes that induce poorer prognosis. Distinct colors have been assigned to each histone modification mark, as indicated in the Figure Legend.

\subsubsection{Histone 3 Lysine 9 (H3K9) and Lysine 36 (H3K36) Methylation}

The methylation of H3K27 can also be regulated by the B cell development transcriptional regulator IKZF1 (also known as Ikaros). It is generally considered to be a tumor suppressor in BCP-ALL [51], given its reported capacity to enrich chromatin with H3K27me3 residues. This effect is mediated by the associated NuRD repressive complex, 
which includes HDAC1, HDAC2, and MI-2 [43,44]. In addition, the proportion of H3K9ac mark skews towards H3K9me3 in the presence of Ikaros and its associated factors, conferring a repressive state to chromatin. Therefore, Ikaros exerts an antioncogenic role, mediated through the repression of some targets involved in cell cycle progression (e.g., $C D C 2$ and $C D C 7$ ), that counteracts EZH2 loss-of-function in BCP-ALL [44]. Pediatric patients with a mutated or impaired Ikaros function are classified as high-risk individuals among BCP-ALL cases [88]. Nonetheless, the function of Ikaros in BCP-ALL merits further study, given that recent data demonstrate it can be induced by the KMT2A-AF4 fusion protein [34]. Consequently, it is tempting to speculate that the repressive role of Ikaros may somehow contribute to the aggressive phenotype presented by patients with $\mathrm{t}(4 ; 11)$ rearrangement.

Another key regulatory residue in terms of leukemic cells transformation is lysine 36 in histone 3 (H3K36). In general, bodies of transcriptionally active genes are decorated with H3K36me2/3 marks, which impair aberrant transcriptional initiation within coding sequences [46]. However, H3K36 is the target of recurrent epigenetic modifications that drive some pediatric cancers. The H3K27me3 and H3K36me3 marks are mutually exclusive, and this antagonism determines the final methylation site and the degree of chromatin accessibility [47]. H3K36 residue methylation is catalyzed by NSD2 methyltransferase, whose catalytic activity depends on the E1099 residue [45,48,49]. A small but significant percentage of infant BCP-ALL cells present a point mutation in this glutamate residue (p.E1099K), which aberrantly triggers cell proliferation. The reversion or depletion of this mutation drastically blocks leukemogenic activity, which makes NSD2 targeting a promising therapy in hematological malignancies [45].

\subsubsection{Other Histone Alterations Affecting Methylation Patterns}

The methylation of histone arginine residues can also influence gene expression, although it has not been thoroughly studied [52]. The regulation of arginine methylation is mediated by protein arginine methyltransferase 5 (PRMT5), which imposes symmetrical dimethylation in substrates like histones $\mathrm{H} 4$ and H2A in BCP-ALL [53]. Through its action on the H4R3 residue, PRMT5 inhibits transcriptional induction at the promoter site of its targets, which include genes, like CLC and CTSB, that are involved in proper B cell differentiation and apoptosis $[52,54]$. Recently, upregulation of symmetric dimethylation of H4R3 (H4R3sme2) has been described in newly diagnosed BCP-ALL infants, as well as in relapsed cases, whereas this mark levels are reduced during remission [52].

KMT2B (also known as MLL2) shares a similar structure (including the SET domain) and methyltransferase function with KMT2A protein [89]. Nevertheless, no translocation of $K M T 2 B$ has been reported in BCP-ALL patients [90], whereas missense mutations and the aberrant activation of its expression have been linked to impaired survival in hematological malignancies [91]. In this sense, KMT2B has been proposed as a potential target in KMT2Arearranged leukemia, given that the deletion of KMT2A-AF9-transformed cells reduces viability and proliferative capacity [92]. Conversely, KMT2B is involved in chromatin silencing via the recruitment of SIRT1. In this case, KMT2B would exert a tumor suppressor function [93].

\subsection{DNA Methylation}

Recent advances in high-throughput DNA sequencing to detect epigenetic changes have considerably increased our knowledge about the importance of epigenetics in leukemogenesis, contributing to the conception that DNA methylation can be used as a biomarker for BCP-ALL classification and outcome prediction [94]. Infant patients who suffer ALL usually experience an adverse outcome, influenced by the high relapse incidence of the disease. Therefore, good biomarkers of potential relapse are highly beneficial for identifying infants at risk of relapse after being treated with current therapies. DNA methylation status can be used both as a biomarker and as a therapy target since it can be reverted with demethylating drugs. 
The availability of DNA methylomes from distinct types of cancer cells has revealed that DNA methylation is frequently altered in leukemic cells and that boundaries between methylated and unmethylated regions are often deregulated [95]. The excessive hypermethylation of CpG islands (CGIs) is the most widely studied of the various alterations affecting DNA methylation [96]. Several studies have demonstrated that BCP-ALL cells display a predominant hypermethylation pattern in CGIs, a general pattern that is shared by all genetic subtypes, commonly affecting the promoter regions of tumor suppressor genes. This pattern of methylation is more frequent in infants and children than in adults, despite the fact that some key gene promoters have been also found hypermethylated in adult B-ALL [97]. Several studies have reported higher methylation levels in malignant cells than in normal hematopoietic B-cell precursors and in matched remission samples of the same patients [98-101]. It can therefore be concluded that many epigenetic changes are required to produce malignant leukemic transformation. Most of the changes occur in regions largely occupied by H3K4me3 and H3K27me3 modifications (discussed in Section 2.2 of this review), which affect genes involved in the loss of plasticity and maintenance of self-renewal capacity [102].

Each ALL subtype (defined by its initiating hits, such as chromosomal translocations) harbors a set of differentially methylated CpGs. These signatures can be used to distinguish between several subtypes:

- High hyperdiploid (HeH) ALL: These cells have a stronger hypomethylation signature than other subtypes of this malignancy [103]. An approximately 5\% lower level of genome methylated CpGs has been found in HeH ALL cells compared with normal B cell precursors [102].

- ETV6-RUNX1 ALL: Cells from this ALL subtype tend to present high levels of DNA methylation [97]. However, the level of expression of IGF2BP1, EPOR, FUCA1 and $H L A-D P B 1$ is higher due to hypomethylation of the promoter regions of these genes [94].

- KMT2A-rearranged ALL: These cases display a greater degree of DNA methylation, mainly in patients with $\mathrm{t}(4 ; 11)$ and $\mathrm{t}(19 ; 11)$ translocations, compared with normal bone marrow cells. Levels of methylation of $t(9 ; 11)$-translocated patients much more closely resemble healthy bone marrow samples [41,94].

- TCF3-PBX1: Given the low incidence of this subtype, DNA methylation levels in these patients have not been widely studied. However, the signature seems mostly to be hypomethylated [104].

- $\quad$ BCR-ABL1 ALL: The Philadelphia chromosome is an indicator of poor prognosis in ALL, and targeted therapies with imatinib or dasatinib are used to treat these patients [104]. Remarkably, DNA methylation plays a secondary role in these patients. In fact, only 271 subtype-specific differentially methylated CpG sites in 36 genes were detected in the $B C R-A B L 1$ ALL subtype, while other subtypes harbored around 2000 differentially methylated CpG sites [100]. The effect of DNA methylation in BCR-ABL1 ALL is probably indirect, and the aberrant alterations in gene expression are far from being a direct consequence of DNA methylation pattern modifications [94].

- Intrachromosomal amplification of chromosome 21 (iAMP21): This subtype has not been widely studied because of its low incidence. However, the signatures of iAMP21 and $\mathrm{HeH}$ cases overlap to some extent [100].

One of the first studies to investigate DNA methylation in BCP-ALL considered chromosome 3, given the presence of several tumor suppressor genes located within its short arm [98]. The PPP2R3A gene was methylated in $82 \%$ of BCP-ALL cases, while FBLN2 and $T H R B$ displayed methylation frequencies over $55 \%$. These methylation patterns were specific to B lymphocyte-derived ALL, rather than to T-ALL [98]. In all cases, the excess methylation was accompanied by the silencing of gene expression.

Some years later, studies of small groups of genes revealed that patients with low levels of methylation are more prone to relapse. However, it has proved difficult to reproduce these results, since methylation signatures present at relapse are rare at the time 
of diagnosis, which makes it difficult to foresee potential relapses depending on the initial methylation signatures $[100,105]$. For instance, the CDKN2A, PTPRO, and COL6A2 genes, which commonly behave as tumor suppressors, are hypermethylated during relapse [106]. Likewise, there is a clear overlap between the CGI methylation pattern in ALL relapse and that of genes regulated during embryonic development [100]. This finding reinforces the fact that BCP-ALL originates during embryonic development and that uncontrolled DNA methylation during this period can result in a poor-prognosis ALL, with a high probability of relapse after initial therapy.

Some genes with an essential role in hematopoietic diseases display an altered methylation pattern within their promoter regions in the context of ALL. These alterations strongly affect the leukemic cell phenotype and disease outcome [107]. This is the case for several tumor suppressor genes, like CDKN2B (also known as p15), CDKN1C (p57), $D L C 1$, and the JAK-STAT-negative regulator PTPN6, whose promoters become aberrantly hypermethylated, causing their expression to be downregulated in BCP-ALL [108-112]. For $C D K N 1 C$, promoter hypermethylation is associated with an adverse outcome [113]. The tumor suppressor TP73, which has a similar function and structure to p53, is hypermethylated in $20-55 \%$ of childhood BCP-ALL cases [114], thereby blocking the apoptotic capacity of leukemic cells. Likewise, $\mathrm{t}(4 ; 11) \mathrm{BCP}$-ALL patients have hypermethylated $D L X$ gene family members (DLX3 and DLX4), which also interferes with apoptotic programs [115]. Conversely, SALL4 gene, which cooperates in maintaining self-renewal of stem cells, displays promoter hypomethylation in BCP-ALL [116].

No solid correlation with promoter DNA methylation has been observed for IKZFI and TET2, two important mediators of B-cell differentiation [107]. IKZF1 promoter is not methylated in healthy B cells [117] and displays a hypermethylation pattern in solid tumors (e.g., lung cancer), although no alterations have been reported for BCP-ALL patients. Similarly, TET2 promoter methylation is not affected in infant ALL [118], whereas it is clearly hypermethylated in acute myeloid leukemia (AML) patients [119].

As discussed in Section 2.2, the KMT2A gene can undergo several rearrangements with alternative partners that confer distinct degrees of aggressiveness on the resulting leukemic clones. Remarkably, a cohort of 26 patients with different chromosomal alterations involving the KMT2A gene has revealed that patients with the $t(4 ; 11)$ translocation, which corresponds to the worst outcome subtype of BCP-ALL, have much more highly hypomethylated enhancer sites than normal BCPs and other KMT2A-rearranged subtypes [57]. The reported hypomethylation sites involve several genes that are differentially expressed in $\mathrm{t}(4 ; 11) \mathrm{BCP}-\mathrm{ALL}$ and thereby contribute to leukemogenesis [57]. This set of genes includes HDAC4 and MSI2, which are correlated with adverse outcomes in KMT2A-rearranged BCP-ALL $[120,121]$ and, more importantly, DOT1L, whose function in triggering progression of leukemogenic cells in this context is described in Section 2.2.

\subsection{Histone acetylation Alterations}

The acetylation of histone lysine residues is one of the most widely documented histone modifications. Alterations in histone acetylation occur in several cancers, including childhood BCP-ALL [60-62]. Global acetylation profile studies have reported a global loss of $\mathrm{H} 4$ acetylation associated with poor outcome [63], while a deficit in $\mathrm{H} 3$ acetylation is correlated with prednisolone resistance in xenograft murine models, driven by the epigenetic silencing of the BIM gene [64].

The regulation of histone lysine acetylation is controlled by a variety of enzymes, the most important of which are the lysine acetyltransferases (KATs) and histone deacetylases (HDACs) [60]. The acetyltransferase CREBBP, whose expression is altered in a variety of cancers, is one of these enzymes $[60,62,65]$. In the context of BCP-ALL, CREBBP is commonly mutated or deleted, and these alterations usually affect the histone acetyltransferase (HAT) domain. Since this CREBBP function is regularly impaired in relapsed patients but is rare in non-relapsing cases, it is believed to induce chemotherapy resistance [122]. The mutations impair acetylation of histones and transcriptional activation of CREBBP targets, 
including genes that are important for conferring glucocorticoid sensitivity on BCP-ALL cells, like RGS16 or DUSP10 [113,114]. CREBBP mutations are also particularly prevalent in cases of BCP-ALL with hyperdiploidy [123].

Likewise, the CREBBP homolog EP300 is involved in a gene fusion (EP300-ZNF384). This is proving to be a novel genomic alteration in BCP-ALL, with an incidence around $2 \%$ in infants, and greater than $5 \%$ in adolescents and young adults [66,124]. This fusion protein not only "reads" chromatin modifications, but also recruits other proteins to the chromatin, for which reason, inhibiting its bromodomain regions, is considered a potential therapeutic strategy [125]. A transcriptomic analysis of samples harboring this alteration shows an aberrant activation of the JAK/STAT pathway, driving leukemia progression [66]. Under normal conditions, the KLF4 transcription factor is acetylated by EP300 and mediates TP53 action by blocking PI3K signaling [126]. When the ZNF384-EP300 fusion protein is expressed, EP300 loses its activity, provoking KLF4 and TP53 dysregulation that, combined with JAK/STAT activation, causes the uncontrolled progression of overt BCP-ALL [66].

A novel recurrent genetic alteration has recently been described in BCP-ALL that consists of an in-frame SLC12A6-NUTM1 fusion [67]. The resulting transcript contains exons 3-8 of the NUTM1 gene and is predicted to encode a chimeric protein, with a binding domain for EP300 [68]. When EP300 is recruited, the SLC2A6-NUTM1 protein acquires transcriptional activity and thereby induces key oncogenic drivers like BMI1, a marker of chemotherapy resistance [67]. A summary of how CREBBP and EP300 mutations induce aberrant activation of BCP-ALL is depicted in Figure 2.

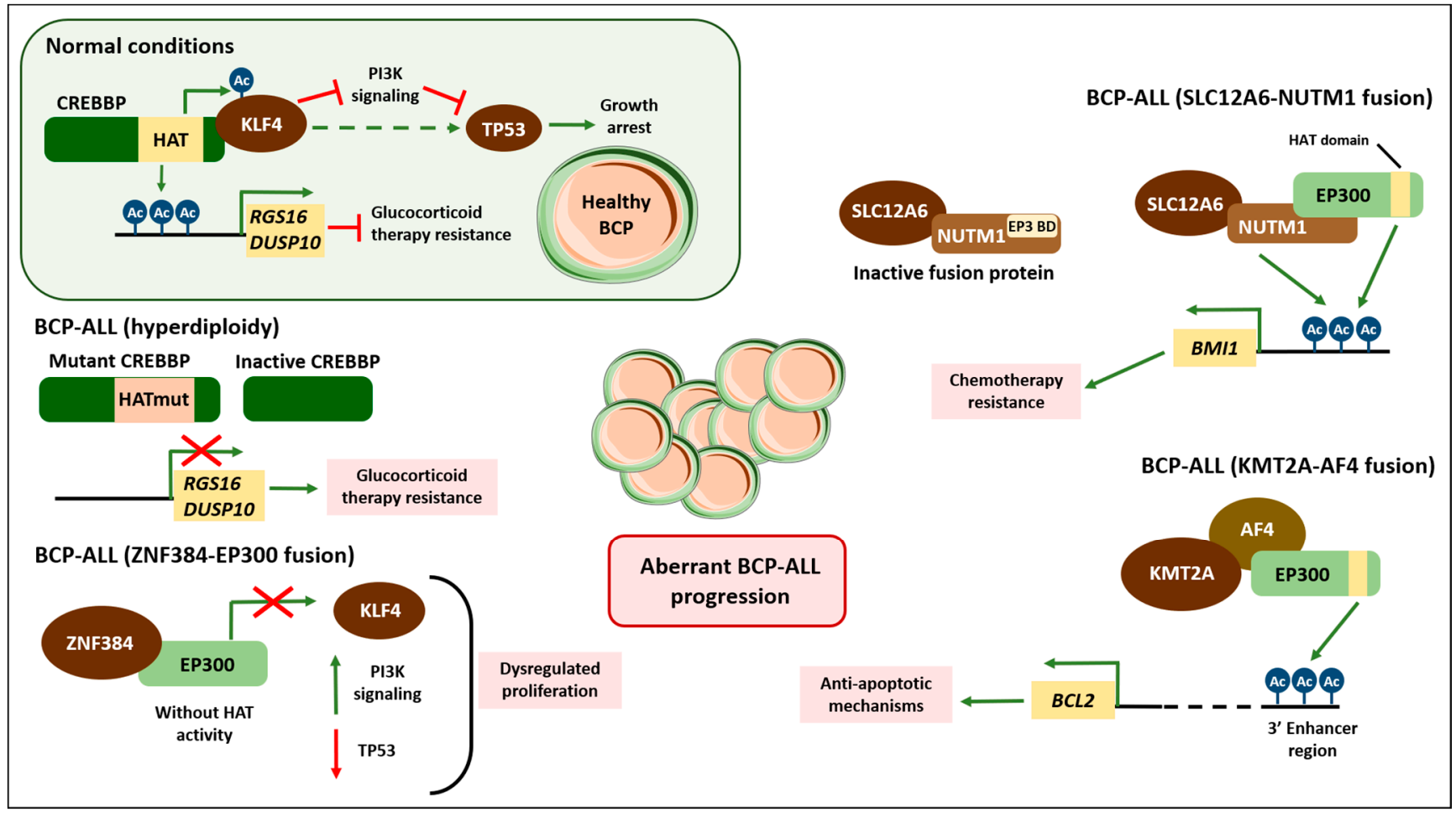

Figure 2. Alterations of histone acetylases drive aberrant BCP-ALL progression. Histone acetylase CREBBP and its homolog EP300 are involved in driving progression of distinct subtypes of BCP-ALL, which displayed the following alterations: ZNF384-EP300, SLC12A6-NUTM1 and KMT2A-AF4 fusions and hyperdiploid BCP-ALL. Inset displaying the role of CREBBP under healthy conditions is colored green. Green arrows indicate activation; red lines and crosses indicate repression. Red squares indicate processes that induce a poorer prognosis. Blue marks labeled "Ac" indicate global histone acetylation, while purple "Ac" marks indicate acetylation of H3K27 residue in the enhancer region of BCL2 (in the context of the KMT2A-AF4 gene rearrangement). EP3 BD refers to EP300 Binding Domain.

The overexpression of some enzymes of the HDAC family (HDAC2, -3, -4, -6, -7, $-8,-9,-11)$ has been linked to an unfavorable prognosis and an impaired response to 
conventional glucocorticoid treatment in two studies $[120,127]$. However, these studies included both B- and T-cell ALL and their associated transcriptional profiles differed profoundly. In fact, the importance of HDAC proteins has been less thoroughly studied even than histone acetyltransferases, and no direct causal association with HDACs has been irrefutably identified [128]. Accordingly, a recent study in our laboratory that looked at BCP-ALL patients with the $t(4 ; 11)$ translocation demonstrated that this aggressive leukemic subtype has almost negligible levels of HDAC7 expression, unlike other subtypes with better outcomes [129]. Therefore, it is tempting to speculate that targeted therapy would benefit from the selective inhibition of specific HDAC proteins, rather than from a complete family blockade.

However, several studies of the use of pan-HDAC inhibitors such as LBH589 (panobinostat) and TSA (trichostatin A) have yielded promising results in terms of synergistic effects with common chemotherapeutic agents [130-132]. Both drugs impose global H3 acetylation, as well as specific acetylation at H3K9 residues in BCP-ALL cells, which compensate the repressive effect of promoter methylation on some tumor suppressor genes, such as the protocadherin PCDH17 [131,132]. Additionally, an unexpected effect on another epigenetic modification, in which H2BK120 ubiquitination was lost upon LBH589 treatment, was found only in KMT2A-rearranged cells [131]. This modification is discussed further in Section 2.5 .

KMT2A rearrangements affect not only the methylation profile of target genes, but also histone acetylation, as exemplified by the regulation of anti-apoptotic genes such as RUNX1, MCL1, and BCL2. The cooperation between KMT2A-AF4 and DOT1L induces their expression through the increased methylation of the H3K79 residue [133]. However, the KMT2A-AF4 fusion protein can also induce BCL2 expression by recruiting EP300 acetyltransferase to an enhancer region located in a $3^{\prime}$ region of the BCL2 gene, which enriches the H3K27ac activating mark in this region [56]. The greater degree of acetylation in these regions is facilitated by the hypomethylation displayed in CGIs located within enhancers [57]. KMT2A-AF4 also associates with other acetyltransferases, such as MOF, which acts on H3K9 and H4K16, imposing active marks such as H4K16ac on promoter regions [59].

In addition to $A F 4, K M T 2 A$ can translocate to other partners, like $E N L$, that also induce typical BCP-ALL markers, such as HOXA9 and MEIS1 [134]. ENL is a potential target in KMT2A-AF4 leukemia, since it is needed to maintain aberrant in vivo and in vitro proliferation, mediated by its YEATS chromatin-reader domain [135]. When ENL is pharmacologically degraded, rapid cell cycle arrest is induced, together with a clear downregulation of HOXA10, MYC, MYB, and MEIS1 expression. Instead, myeloid markers like $C D 11 B$ are upregulated. ChIP-seq data show that ENL binds to promoter regions of these targets, enriched in H3K9ac, H3K18ac and H3K27ac through the YEATS domain [135], which have been reported as being gene activation marks $[56,58,59]$. These data indicate that KMT2A-rearranged BCP-ALL can also progress through alternative mechanisms in a DOT1L-independent fashion.

\subsection{Histone Ubiquitination Alterations}

The histone H2A mono-ubiquitylation mark confers low transcriptional activity on genes. Conversely, H2B ubiquitination at Lys120 (H2BK120ub) induces transcriptional elongation and facilitates H3 methylation [69]. The methylation of H3K4 and H3K79 residues, mediated by KMT2A and DOT1L enzymes, respectively, take place through an $\mathrm{H} 2 \mathrm{~B}$-ubiquitin-dependent mechanism [70,71]. In the context of KMT2A-rearranged BCP-ALL, mechanistic studies have sought to define how DOT1L is aberrantly activated and leads to an excess of H3K79 methylation [69,82]. The disulfide-directed methodology developed by Chatterjee et al. [69] revealed that the stimulatory effect not only occurs upon H2B ubiquitination in Lys120 but can also be mirrored by ubiquitination at other positions in the K120 surrounding area. For instance, H2BK125ub, whose specific function in human cells is not known, exhibits similar activity to that of the native K120 site [69]. 
The localization pattern of the H2Bub chromatin mark resembles that of H3K79me2. Importantly, the knockdown of KMT2A-AF9 fusion protein in $\mathrm{t}(9 ; 11)$-rearranged ALL cells triggers a concomitant downregulation of both H3K79me2 and H2Bub marks, indicating that these two events, which cooperate in RNA polymerase II transcription elongation [81], are somehow interconnected [136]. Additionally, the presence of H2Bub mark is required to maintain DOT1L activity and, therefore, to keep high levels of H3K79me2 in KMT2A-fusion proteins targets [136].

The incorporation of the H2BK120ub mark depends on the BRE1 protein complex, which includes the protein-protein adaptor WAC and ubiquitin ligase RNF20, which is the major E3 ligase that catalyzes ubiquitination of H2B in mammalian cells [137]. RNF20 has been defined as an essential regulator of chromatin accessibility, required for leukemogenesis mediated by KMT2A-fusion proteins [136]. The pan-HDAC inhibitor LBH589 provokes RNF20 downregulation in patients with KMT2A rearrangement, inducing not only acetylation loss, but also a decrease in the levels of H2BK120ub mark [131].

\section{Concluding Remarks}

As described throughout this review, strict control of the epigenetic mechanisms that drive $B$ lymphocyte differentiation can be easily disrupted at several points, giving rise to infant BCP-ALL. In fact, the initial hit occurring during embryogenesis commonly involves chromosomal rearrangements affecting genes with methyltransferase activity (such as $K M T 2 A)$, resulting in increased catalytic activity that is exacerbated by interaction with other cofactors. Remarkably, methylation, acetylation or ubiquitination of several histone residues (H2BK120, H3K4, H3K9, H3K27, H3K36, H3K79, H4K16, and H4R3) can trigger a variety of processes related to leukemogenic cell capacity, either inducing or repressing it. In some specific residues, such as in the case of H3K27, acetylation and methylation determine the accessibility of transcription factors to chromatin. However, depending on the genomic region involved, the epigenetic modification of histone residues has distinct outputs in terms of cell viability, aberrant proliferation and/or resistance to chemotherapy. In consequence, obtaining a full epigenomic profile of BCP-ALL infants would promote the development of novel therapies focused on reverting key epigenetic alterations that drive this malignancy. As an example, an integrative epigenomic analysis performed in adult B-ALL provided the basis for a clinical trial with BCL6 inhibitors in specific cases of B-ALL with a concrete epigenetic alteration [138].

Apart from providing a better understanding of the molecular effects beyond epigenetic gene regulation, we provide further insight into the clinical relevance of epigenetic modifications. For instance, the DNA methylation signature can be used to assign BCPALL cases to a specific subtype and to predict disease outcome, while loss-of-function mutations in methyltransferases (such as NSD2) or KATS (like CREBBP or EP300) may be used to predict prognosis and response to chemotherapy. In this sense, the epigenetic alterations reported here constitute a potential entry point for therapeutic approaches for BCP-ALL. In fact, compounds blocking DOT1L activity or impairing binding between KMT2A-AF4 aberrant protein and its cofactor Menin are already undergoing clinical trials for the treatment of hematological diseases $[85,90]$, with the promise of a novel treatment for BCP-ALL in the near future. Therefore, we believe that further research on epigenetic processes will give rise to effective therapies that, alone or in combination with current therapies, will improve the prognosis of infant BCP-ALL.

Author Contributions: Bibliographic research, O.d.B.; writing-original draft preparation, O.d.B.; writing-review and editing, M.P.; conceptualization, O.d.B. and M.P.; supervision, M.P. All authors have read and agreed to the published version of the manuscript.

Funding: This work was funded by grants to MP from the Spanish Ministry of Science, Innovation and Universities (SAF2017-87990-R, approved on 1 January 2018, and EUR2019-103835, approved on 1 October 2019) and carried out at the Josep Carreras Leukaemia Research Institute (IJC, Badalona, Barcelona). OdB was funded by a Juan de la Cierva Formación Fellowship from the Spanish Ministry of Science, Innovation and Universities (FJCI-2017-32430, approved on 1 January 
2019) and by a Postdoctoral Fellowship from the Asociación Española Contra el Cáncer (AECC) Foundation (POSTD20024DEBA grant, approved on 1 December 2020). We thank the CERCA Programme/Generalitat de Catalunya for institutional support.

Institutional Review Board Statement: Not applicable.

Informed Consent Statement: Not applicable.

Data Availability Statement: Not applicable.

Conflicts of Interest: The authors declare no conflict of interest.

\section{References}

1. Pui, C.-H.; Evans, W.E. A 50-Year Journey to Cure Childhood Acute Lymphoblastic Leukemia. Semin. Hematol. 2013, 50, 185-196. [CrossRef]

2. Pui, C.-H.; Mullighan, C.G.; Evans, W.E.; Relling, M.V. Pediatric acute lymphoblastic leukemia: Where are we going and how do we get there? Blood 2012, 120, 1165-1174. [CrossRef]

3. Greaves, M. A causal mechanism for childhood acute lymphoblastic leukaemia. Nat. Rev. Cancer 2018, 18, 471-484. [CrossRef] [PubMed]

4. Hunger, S.P.; Mullighan, C.G. Acute Lymphoblastic Leukemia in Children. N. Engl. J. Med. 2015, 373, 1541-1552. [CrossRef] [PubMed]

5. Bueno, C.; Montes, R.; Catalina, P.; Rodríguez, R.; Menendez, P. Insights into the cellular origin and etiology of the infant pro-B acute lymphoblastic leukemia with MLL-AF4 rearrangement. Leukemia 2011, 25, 400-410. [CrossRef]

6. Sanjuan-Pla, A.; Bueno, C.; Prieto, C.; Acha, P.; Stam, R.W.; Marschalek, R.; Menéndez, P. Revisiting the biology of infant $\mathrm{t}(4 ; 11)$ /MLL-AF4+ B-cell acute lymphoblastic leukemia. Blood 2015, 126, 2676-2685. [CrossRef] [PubMed]

7. Stam, R.W.; Schneider, P.; Hagelstein, J.A.P.; van der Linden, M.H.; Stumpel, D.J.P.M.; de Menezes, R.X.; de Lorenzo, P.; Valsecchi, M.G.; Pieters, R. Gene expression profiling-based dissection of MLL translocated and MLL germline acute lymphoblastic leukemia in infants. Blood 2010, 115, 2835-2844. [CrossRef]

8. Agraz-Doblas, A.; Bueno, C.; Bashford-Rogers, R.; Roy, A.; Schneider, P.; Bardini, M.; Ballerini, P.; Cazzaniga, G.; Moreno, T.; Revilla, C.; et al. Unraveling the cellular origin and clinical prognostic markers of infant B-cell acute lymphoblastic leukemia using genome-wide analysis. Haematologica 2019, 104, 1176-1188. [CrossRef]

9. Imamura, T.; Morimoto, A.; Takanashi, M.; Hibi, S.; Sugimoto, T.; Ishii, E.; Imashuku, S. Frequent co-expression of HoxA9 and Meis1 genes in infant acute lymphoblastic leukaemia with MLL rearrangement. Br. J. Haematol. 2002, 119, 119-121. [CrossRef]

10. Lim, D.A.; Huang, Y.-C.; Swigut, T.; Mirick, A.L.; Garcia-Verdugo, J.M.; Wysocka, J.; Ernst, P.; Alvarez-Buylla, A. Chromatin remodelling factor Mll1 is essential for neurogenesis from postnatal neural stem cells. Nature 2009, 458, 529-533. [CrossRef]

11. Orlovsky, K.; Kalinkovich, A.; Rozovskaia, T.; Shezen, E.; Itkin, T.; Alder, H.; Ozer, H.G.; Carramusa, L.; Avigdor, A.; Volinia, S.; et al. Down-regulation of homeobox genes MEIS1 and HOXA in MLL-rearranged acute leukemia impairs engraftment and reduces proliferation. Proc. Natl. Acad. Sci. USA 2011, 108, 7956-7961. [CrossRef]

12. Chillón, M.C.; Gómez-Casares, M.T.; López-Jorge, C.E.; Rodriguez-Medina, C.; Molines, A.; Sarasquete, M.E.; Alcoceba, M.; Miguel, J.D.G.-S.; Bueno, C.; Montes, R.; et al. Prognostic significance of FLT3 mutational status and expression levels in MLL-AF4+ and MLL-germline acute lymphoblastic leukemia. Leukemia 2012, 26, 2360-2366. [CrossRef]

13. Brown, P.; Levis, M.; Shurtleff, S.; Campana, D.; Downing, J.; Small, D. FLT3 inhibition selectively kills childhood acute lymphoblastic leukemia cells with high levels of FLT3 expression. Blood 2005, 105, 812-820. [CrossRef]

14. Stam, R.W.; Schneider, P.; de Lorenzo, P.; Valsecchi, M.G.; den Boer, M.L.; Pieters, R. Prognostic significance of high-level FLT3 expression in MLL-rearranged infant acute lymphoblastic leukemia. Blood 2007, 110, 2774-2775. [CrossRef]

15. Brown, P.A.; Kairalla, J.A.; Hilden, J.M.; Dreyer, Z.E.; Carroll, A.J.; Heerema, N.A.; Wang, C.; Devidas, M.; Gore, L.; Salzer, W.L.; et al. FLT3 inhibitor lestaurtinib plus chemotherapy for newly diagnosed KMT2A-rearranged infant acute lymphoblastic leukemia: Children's Oncology Group trial AALL0631. Leukemia 2021. [CrossRef]

16. Campos-Sanchez, E.; Toboso-Navasa, A.; Romero-Camarero, I.; Barajas-Diego, M.; Sánchez-García, I.; Cobaleda, C. Acute lymphoblastic leukemia and developmental biology. Cell Cycle 2011, 10, 3473-3486. [CrossRef]

17. Greaves, M. Infection, immune responses and the aetiology of childhood leukaemia. Nat. Rev. Cancer 2006, 6, 193-203. [CrossRef]

18. Milne, T.A.; Briggs, S.D.; Brock, H.W.; Martin, M.E.; Gibbs, D.; Allis, C.D.; Hess, J.L. MLL Targets SET Domain Methyltransferase Activity to Hox Gene Promoters. Mol. Cell 2002, 10, 1107-1117. [CrossRef]

19. Yu, J.-R.; Lee, C.-H.; Oksuz, O.; Stafford, J.M.; Reinberg, D. PRC2 is high maintenance. Genes Dev. 2019, 33, 903-935. [CrossRef]

20. Roberts, K.G. Genetics and prognosis of ALL in children vs adults. Hematol. Am. Soc. Hematol. Educ. Program. 2018, 1, 137-145. [CrossRef]

21. Mohammad, H.P.; Barbash, O.; Creasy, C.L. Targeting epigenetic modifications in cancer therapy: Erasing the roadmap to cancer. Nat. Med. 2019, 25, 403-418. [CrossRef]

22. Pfister, S.X.; Ashworth, A. Marked for death: Targeting epigenetic changes in cancer. Nat. Rev. Drug Discov. 2017, 16, 241-263. [CrossRef]

23. Flavahan, W.A.; Gaskell, E.; Bernstein, B.E. Epigenetic plasticity and the hallmarks of cancer. Science 2017, 357, eaal2380. [CrossRef]

24. Krivtsov, A.V.; Hoshii, T.; Armstrong, S.A. Mixed-Lineage Leukemia Fusions and Chromatin in Leukemia. Cold Spring Harb. Perspect. Med. 2017, 7, a026658. [CrossRef]

25. Rea, S.; Eisenhaber, F.; O'Carroll, D.; Strahl, B.D.; Sun, Z.-W.; Schmid, M.; Opravil, S.; Mechtler, K.; Ponting, C.P.; Allis, C.D.; et al. Regulation of chromatin structure by site-specific histone H3 methyltransferases. Nature 2000, 406, 593-599. [CrossRef] 
26. Crump, N.T.; Milne, T.A. Why are so many MLL lysine methyltransferases required for normal mammalian development? Cell. Mol. Life Sci. 2019, 76, 2885-2898. [CrossRef]

27. Meyer, C.; Burmeister, T.; Gröger, D.; Tsaur, G.; Fechina, L.; Renneville, A.; Sutton, R.; Venn, N.C.; Emerenciano, M.; Pombo-de-Oliveira, M.S.; et al. The MLL recombinome of acute leukemias in 2017. Leukemia 2018, 32, 273-284. [CrossRef]

28. Rice, S.; Roy, A. MLL-rearranged infant leukaemia: A 'thorn in the side' of a remarkable success story. Biochim. Biophys. Acta Gene Regul. Mech. 2020, 1863, 194564. [CrossRef]

29. Wood, A.; Schneider, J.; Dover, J.; Johnston, M.; Shilatifard, A. The Paf1 Complex Is Essential for Histone Monoubiquitination by the Rad6-Bre1 Complex, Which Signals for Histone Methylation by COMPASS and Dot1p. J. Biol. Chem. 2003, 278, 34739-34742. [CrossRef]

30. Yokoyama, A.; Somervaille, T.C.P.; Smith, K.S.; Rozenblatt-Rosen, O.; Meyerson, M.; Cleary, M.L. The Menin Tumor Suppressor Protein Is an Essential Oncogenic Cofactor for MLL-Associated Leukemogenesis. Cell 2005, 123, 207-218. [CrossRef]

31. Milne, T.A.; Kim, J.; Wang, G.G.; Stadler, S.C.; Basrur, V.; Whitcomb, S.J.; Wang, Z.; Ruthenburg, A.J.; Elenitoba-Johnson, K.S.J.; Roeder, R.G.; et al. Multiple Interactions Recruit MLL1 and MLL1 Fusion Proteins to the HOXA9 Locus in Leukemogenesis. Mol. Cell 2010, 38, 853-863. [CrossRef]

32. Muntean, A.G.; Tan, J.; Sitwala, K.; Huang, Y.; Bronstein, J.; Connelly, J.A.; Basrur, V.; Elenitoba-Johnson, K.S.J.; Hess, J.L. The PAF Complex Synergizes with MLL Fusion Proteins at HOX Loci to Promote Leukemogenesis. Cancer Cell 2010, 17, 609-621. [CrossRef] [PubMed]

33. Yang, M.; Safavi, S.; Woodward, E.L.; Duployez, N.; Olsson-Arvidsson, L.; Ungerbäck, J.; Sigvardsson, M.; Zaliova, M.; Zuna, J.; Fioretos, T.; et al. 13q12.2 deletions in acute lymphoblastic leukemia lead to upregulation of FLT3 through enhancer hijacking. Blood 2020, 136, 946-956. [CrossRef]

34. Malouf, C.; Ottersbach, K. The fetal liver lymphoid-primed multipotent progenitor provides the prerequisites for the initiation of t(4;11) MLL-AF4 infant leukemia. Haematologica 2018, 103, e571-e574. [CrossRef] [PubMed]

35. Zeisig, D.T.; Bittner, C.B.; Zeisig, B.B.; García-Cuéllar, M.-P.; Hess, J.L.; Slany, R.K. The eleven-nineteen-leukemia protein ENL connects nuclear MLL fusion partners with chromatin. Oncogene 2005, 24, 5525-5532. [CrossRef]

36. Bitoun, E.; Oliver, P.L.; Davies, K.E. The mixed-lineage leukemia fusion partner AF4 stimulates RNA polymerase II transcriptional elongation and mediates coordinated chromatin remodeling. Hum. Mol. Genet. 2007, 16, 92-106. [CrossRef]

37. Steinhilber, D.; Marschalek, R. How to effectively treat acute leukemia patients bearing MLL-rearrangements? Biochem. Pharmacol. 2018, 147, 183-190. [CrossRef]

38. Benedikt, A.; Baltruschat, S.; Scholz, B.; Bursen, A.; Arrey, T.N.; Meyer, B.; Varagnolo, L.; Müller, A.M.; Karas, M.; Dingermann, T.; et al. The leukemogenic AF4-MLL fusion protein causes P-TEFb kinase activation and altered epigenetic signatures. Leukemia 2011, 25, 135-144. [CrossRef]

39. Kerry, J.; Godfrey, L.; Repapi, E.; Tapia, M.; Blackledge, N.P.; Ma, H.; Ballabio, E.; O’Byrne, S.; Ponthan, F.; Heidenreich, O.; et al. MLL-AF4 Spreading Identifies Binding Sites that Are Distinct from Super-Enhancers and that Govern Sensitivity to DOT1L Inhibition in Leukemia. Cell Rep. 2017, 18, 482-495. [CrossRef]

40. Godfrey, L.; Crump, N.T.; Thorne, R.; Lau, I.-J.; Repapi, E.; Dimou, D.; Smith, A.L.; Harman, J.R.; Telenius, J.M.; Oudelaar, A.M.; et al. DOT1L inhibition reveals a distinct subset of enhancers dependent on H3K79 methylation. Nat. Commun. 2019, 10, 2803. [CrossRef]

41. Stumpel, D.J.P.M.; Schneider, P.; van Roon, E.H.J.; Boer, J.M.; de Lorenzo, P.; Valsecchi, M.G.; de Menezes, R.X.; Pieters, R.; Stam, R.W. Specific promoter methylation identifies different subgroups of MLL-rearranged infant acute lymphoblastic leukemia, influences clinical outcome, and provides therapeutic options. Blood 2009, 114, 5490-5498. [CrossRef]

42. Chen, C.-W.; Koche, R.P.; Sinha, A.U.; Deshpande, A.J.; Zhu, N.; Eng, R.; Doench, J.G.; Xu, H.; Chu, S.H.; Qi, J.; et al. DOT1L inhibits SIRT1-mediated epigenetic silencing to maintain leukemic gene expression in MLL-rearranged leukemia. Nat. Med. 2015, 21, 335-343. [CrossRef]

43. Zhang, J.; Jackson, A.F.; Naito, T.; Dose, M.; Seavitt, J.; Liu, F.; Heller, E.J.; Kashiwagi, M.; Yoshida, T.; Gounari, F.; et al. Harnessing of the nucleosome-remodeling-deacetylase complex controls lymphocyte development and prevents leukemogenesis. Nat. Immunol. 2012, 13, 86-94. [CrossRef] [PubMed]

44. Song, C.; Pan, X.; Ge, Z.; Gowda, C.; Ding, Y.; Li, H.; Li, Z.; Yochum, G.; Muschen, M.; Li, Q.; et al. Epigenetic regulation of gene expression by Ikaros, HDAC1 and Casein Kinase II in leukemia. Leukemia 2016, 30, 1436-1440. [CrossRef]

45. Jaffe, J.D.; Wang, Y.; Chan, H.M.; Zhang, J.; Huether, R.; Kryukov, G.V.; Bhang, H.C.; Taylor, J.E.; Hu, M.; Englund, N.P.; et al. Global chromatin profiling reveals NSD2 mutations in pediatric acute lymphoblastic leukemia. Nat. Genet. 2013, 45, 1386-1391. [CrossRef]

46. Mohammad, F.; Helin, K. Oncohistones: Drivers of pediatric cancers. Genes Dev. 2017, 31, 2313-2324. [CrossRef]

47. Alabert, C.; Loos, C.; Voelker-Albert, M.; Graziano, S.; Forné, I.; Reveron-Gomez, N.; Schuh, L.; Hasenauer, J.; Marr, C.; Imhof, A.; et al. Domain Model Explains Propagation Dynamics and Stability of Histone H3K27 and H3K36 Methylation Landscapes. Cell Rep. 2020, 30, 1223-1234. [CrossRef]

48. Li, Y.; Trojer, P.; Xu, C.-F.; Cheung, P.; Kuo, A.; Drury, W.J.; Qiao, Q.; Neubert, T.A.; Xu, R.-M.; Gozani, O.; et al. The Target of the NSD Family of Histone Lysine Methyltransferases Depends on the Nature of the Substrate. J. Biol. Chem. 2009, 284, 34283-34295. [CrossRef]

49. Kuo, A.J.; Cheung, P.; Chen, K.; Zee, B.M.; Kioi, M.; Lauring, J.; Xi, Y.; Park, B.H.; Shi, X.; Garcia, B.A.; et al. NSD2 Links Dimethylation of Histone H3 at Lysine 36 to Oncogenic Programming. Mol. Cell 2011, 44, 609-620. [CrossRef]

50. Ernst, T.; Chase, A.J.; Score, J.; Hidalgo-Curtis, C.E.; Bryant, C.; Jones, A.V.; Waghorn, K.; Zoi, K.; Ross, F.M.; Reiter, A.; et al. Inactivating mutations of the histone methyltransferase gene EZH2 in myeloid disorders. Nat. Genet. 2010, 42, 722-726. [CrossRef] 
51. Georgopoulos, K.; Bigby, M.; Wang, J.-H.; Molnar, A.; Wu, P.; Winandy, S.; Sharpe, A. The ikaros gene is required for the development of all lymphoid lineages. Cell 1994, 79, 143-156. [CrossRef]

52. Mei, M.; Zhang, R.; Zhou, Z.; Ying, Z.; Wang, J.; Zhang, H.; Zheng, H.; Bao, S. PRMT5-mediated H4R3sme2 confers cell differentiation in Pediatric B-cell Precursor Acute Lymphoblastic Leukemia. Clin. Cancer Res. 2019, 25, 2633-2643. [CrossRef]

53. Blanc, R.S.; Richard, S. Arginine Methylation: The Coming of Age. Mol. Cell 2017, 65, 8-24. [CrossRef] [PubMed]

54. Lalanne, A.I.; Moraga, I.; Hao, Y.; Pereira, J.P.; Alves, N.L.; Huntington, N.D.; Freitas, A.A.; Cumano, A.; Vieira, P. CpG Inhibits Pro-B Cell Expansion through a Cathepsin B-Dependent Mechanism. J. Immunol. 2010, 184, 5678-5685. [CrossRef] [PubMed]

55. Jing, D.; Huang, Y.; Liu, X.; Sia, K.C.S.; Zhang, J.C.; Tai, X.; Wang, M.; Toscan, C.E.; McCalmont, H.; Evans, K.; et al. LymphocyteSpecific Chromatin Accessibility Pre-determines Glucocorticoid Resistance in Acute Lymphoblastic Leukemia. Cancer Cell 2018, 34, 906-921. [CrossRef]

56. Godfrey, L.; Kerry, J.; Thorne, R.; Repapi, E.; Davies, J.O.J.; Tapia, M.; Ballabio, E.; Hughes, J.R.; Geng, H.; Konopleva, M.; et al. MLL-AF4 binds directly to a BCL-2 specific enhancer and modulates H3K27 acetylation. Exp. Hematol. 2017, 47, 64-75. [CrossRef]

57. Bergmann, A.K.; Castellano, G.; Alten, J.; Ammerpohl, O.; Kolarova, J.; Nordlund, J.; Martin-Subero, J.I.; Schrappe, M.; Siebert, R. DNA methylation profiling of pediatric B-cell lymphoblastic leukemia with KMT2A rearrangement identifies hypomethylation at enhancer sites. Pediatr. Blood Cancer 2017, 64, e26251. [CrossRef]

58. Kasper, L.H.; Lerach, S.; Wang, J.; Wu, S.; Jeevan, T.; Brindle, P.K. CBP/p300 double null cells reveal effect of coactivator level and diversity on CREB transactivation. EMBO J 2010, 29, 3660-3672. [CrossRef]

59. Dou, Y.; Milne, T.A.; Tackett, A.J.; Smith, E.R.; Fukuda, A.; Wysocka, J.; Allis, C.D.; Chait, B.T.; Hess, J.L.; Roeder, R.G. Physical Association and Coordinate Function of the H3 K4 Methyltransferase MLL1 and the H4 K16 Acetyltransferase MOF. Cell 2005, 121, 873-885. [CrossRef] [PubMed]

60. Kouzarides, T. Chromatin Modifications and Their Function. Cell 2007, 128, 693-705. [CrossRef] [PubMed]

61. Huether, R.; Dong, L.; Chen, X.; Wu, G.; Parker, M.; Wei, L.; Ma, J.; Edmonson, M.N.; Hedlund, E.K.; Rusch, M.C.; et al. The landscape of somatic mutations in epigenetic regulators across 1,000 paediatric cancer genomes. Nat. Commun. 2014, 5, 3630. [CrossRef]

62. Janczar, S.; Janczar, K.; Pastorczak, A.; Harb, H.; Paige, A.; Zalewska-Szewczyk, B.; Danilewicz, M.; Mlynarski, W. The Role of Histone Protein Modifications and Mutations in Histone Modifiers in Pediatric B-Cell Progenitor Acute Lymphoblastic Leukemia. Cancers 2017, 9, 2. [CrossRef]

63. Janczar, K.; Janczar, S.; Pastorczak, A.; Mycko, K.; Paige, A.J.W.; Zalewska-Szewczyk, B.; Wagrowska-Danilewicz, M.; Danilewicz, M.; Mlynarski, W. Preserved global histone H4 acetylation linked to ETV6-RUNX1 fusion and PAX5 deletions is associated with favorable outcome in pediatric B-cell progenitor acute lymphoblastic leukemia. Leuk. Res. 2015, 39, 1455-1461. [CrossRef] [PubMed]

64. Bachmann, P.S.; Piazza, R.G.; Janes, M.E.; Wong, N.C.; Davies, C.; Mogavero, A.; Bhadri, V.A.; Szymanska, B.; Geninson, G.; Magistroni, V.; et al. Epigenetic silencing of BIM in glucocorticoid poor-responsive pediatric acute lymphoblastic leukemia, and its reversal by histone deacetylase inhibition. Blood 2010, 116, 3013-3022. [CrossRef] [PubMed]

65. Kouzarides, T. SnapShot: Histone-Modifying Enzymes. Cell 2007, 131, 822-e1. [CrossRef] [PubMed]

66. McClure, B.J.; Heatley, S.L.; Kok, C.H.; Sadras, T.; An, J.; Hughes, T.P.; Lock, R.B.; Yeung, D.; Sutton, R.; White, D.L. Pre-B acute lymphoblastic leukaemia recurrent fusion, EP300-ZNF384, is associated with a distinct gene expression. Br. J. Cancer 2018, 118, 1000-1004. [CrossRef]

67. Hormann, F.M.; Hoogkamer, A.Q.; Beverloo, H.B.; Boeree, A.; Dingjan, I.; Wattel, M.M.; Stam, R.W.; Escherich, G.; Pieters, R.; Den Boer, M.L.; et al. NUTM1 is a recurrent fusion gene partner in B-cell precursor acute lymphoblastic leukemia associated with increased expression of genes on chromosome band 10p12.31-12.2. Haematologica 2019, 104, E455-E459. [CrossRef]

68. Reynoird, N.; Schwartz, B.E.; Delvecchio, M.; Sadoul, K.; Meyers, D.; Mukherjee, C.; Caron, C.; Kimura, H.; Rousseaux, S.; Cole, P.A.; et al. Oncogenesis by sequestration of $\mathrm{CBP} /$ p300 in transcriptionally inactive hyperacetylated chromatin domains. EMBO J. 2010, 29, 2943-2952. [CrossRef] [PubMed]

69. Chatterjee, C.; McGinty, R.K.; Fierz, B.; Muir, T.W. Disulfide-directed histone ubiquitylation reveals plasticity in hDot1L activation. Nat. Chem. Biol. 2010, 6, 267-269. [CrossRef]

70. Kim, J.; Guermah, M.; McGinty, R.K.; Lee, J.-S.; Tang, Z.; Milne, T.A.; Shilatifard, A.; Muir, T.W.; Roeder, R.G. RAD6-Mediated Transcription-Coupled H2B Ubiquitylation Directly Stimulates H3K4 Methylation in Human Cells. Cell 2009, 137, 459-471. [CrossRef]

71. McGinty, R.K.; Kim, J.; Chatterjee, C.; Roeder, R.G.; Muir, T.W. Chemically ubiquitylated histone H2B stimulates hDot1L-mediated intranucleosomal methylation. Nature 2008, 453, 812-816. [CrossRef] [PubMed]

72. Rowley, J.D. Rearrangements involving chromosome band 11Q23 in acute leukemia. Semin. Cancer Biol. 1993, 4, 377-385. [PubMed]

73. Dou, Y.; Milne, T.A.; Ruthenburg, A.J.; Lee, S.; Lee, J.W.; Verdine, G.L.; Allis, C.D.; Roeder, R.G. Regulation of MLL1 H3K4 methyltransferase activity by its core components. Nat. Struct. Mol. Biol. 2006, 13, 713-719. [CrossRef]

74. Southall, S.M.; Wong, P.-S.; Odho, Z.; Roe, S.M.; Wilson, J.R. Structural Basis for the Requirement of Additional Factors for MLL1 SET Domain Activity and Recognition of Epigenetic Marks. Mol. Cell 2009, 33, 181-191. [CrossRef]

75. Wang, Z.-H.; Li, D.-D.; Chen, W.-L.; You, Q.-D.; Guo, X.-K. Targeting protein-protein interaction between MLL1 and reciprocal proteins for leukemia therapy. Bioorg. Med. Chem. 2018, 26, 356-365. [CrossRef]

76. Li, Y.; Han, J.; Zhang, Y.; Cao, F.; Liu, Z.; Li, S.; Wu, J.; Hu, C.; Wang, Y.; Shuai, J.; et al. Structural basis for activity regulation of MLL family methyltransferases. Nature 2016, 530, 447-452. [CrossRef] [PubMed]

77. Wang, Z.; Song, J.; Milne, T.A.; Wang, G.G.; Li, H.; Allis, C.D.; Patel, D.J. Pro Isomerization in MLL1 PHD3-Bromo Cassette Connects H3K4me Readout to CyP33 and HDAC-Mediated Repression. Cell 2010, 141, 1183-1194. [CrossRef] 
78. Rössler, T.; Marschalek, R. An alternative splice process renders MLL either into a transcriptional activator or repressor. Pharmazie 2013, 68, 601-607. [CrossRef]

79. Nakamura, T.; Mori, T.; Tada, S.; Krajewski, W.; Rozovskaia, T.; Wassell, R.; Dubois, G.; Mazo, A.; Croce, C.M.; Canaani, E. ALL-1 Is a Histone Methyltransferase that Assembles a Supercomplex of Proteins Involved in Transcriptional Regulation. Mol. Cell 2002, 10, 1119-1128. [CrossRef]

80. Krivtsov, A.V.; Feng, Z.; Lemieux, M.E.; Faber, J.; Vempati, S.; Sinha, A.U.; Xia, X.; Jesneck, J.; Bracken, A.P.; Silverman, L.B.; et al. H3K79 Methylation Profiles Define Murine and Human MLL-AF4 Leukemias. Cancer Cell 2008, 14, 355-368. [CrossRef]

81. Steger, D.J.; Lefterova, M.I.; Ying, L.; Stonestrom, A.J.; Schupp, M.; Zhuo, D.; Vakoc, A.L.; Kim, J.-E.; Chen, J.; Lazar, M.A.; et al. DOT1L/KMT4 Recruitment and H3K79 Methylation Are Ubiquitously Coupled with Gene Transcription in Mammalian Cells. Mol. Cell. Biol. 2008, 28, 2825-2839. [CrossRef]

82. Okada, Y.; Feng, Q.; Lin, Y.; Jiang, Q.; Li, Y.; Coffield, V.M.; Su, L.; Xu, G.; Zhang, Y. hDOT1L Links Histone Methylation to Leukemogenesis. Cell 2005, 121, 167-178. [CrossRef]

83. Kühn, A.; Löscher, D.; Marschalek, R. The IRX1/HOXA connection: Insights into a novel t(4;11)-specific cancer mechanism. Oncotarget 2016, 7, 35341-35352. [CrossRef] [PubMed]

84. Kang, H.; Wilson, C.S.; Harvey, R.C.; Chen, I.-M.; Murphy, M.H.; Atlas, S.R.; Bedrick, E.J.; Devidas, M.; Carroll, A.J.; Robinson, B.W.; et al. Gene expression profiles predictive of outcome and age in infant acute lymphoblastic leukemia: A Children's Oncology Group study. Blood 2012, 119, 1872-1881. [CrossRef]

85. Bushweller, J.H. Targeting transcription factors in cancer-from undruggable to reality. Nat. Rev. Cancer 2019, 19, 611-624. [CrossRef] [PubMed]

86. Azagra, A.; Marina-Zárate, E.; Ramiro, A.R.; Javierre, B.M.; Parra, M. From Loops to Looks: Transcription Factors and Chromatin Organization Shaping Terminal B Cell Differentiation. Trends Immunol. 2020, 41, 46-60. [CrossRef]

87. de la Rica, L.; Rodríguez-Ubreva, J.; García, M.; Islam, A.B.; Urquiza, J.M.; Hernando, H.; Christensen, J.; Helin, K.; Gómez-Vaquero, C.; Ballestar, E. PU.1 target genes undergo Tet2-coupled demethylation and DNMT3b-mediated methylation in monocyte-to-osteoclast differentiation. Genome Biol. 2013, 14, R99. [CrossRef]

88. Song, C.; Gowda, C.; Pan, X.; Ding, Y.; Tong, Y.; Tan, B.-H.; Wang, H.; Muthusami, S.; Ge, Z.; Sachdev, M.; et al. Targeting casein kinase II restores Ikaros tumor suppressor activity and demonstrates therapeutic efficacy in high-risk leukemia. Blood 2015, 126, 1813-1822. [CrossRef] [PubMed]

89. Rao, R.C.; Dou, Y. Hijacked in cancer: The KMT2 (MLL) family of methyltransferases. Nat. Rev. Cancer 2015, 15, 334-346. [CrossRef] [PubMed]

90. Ye, F.; Huang, J.; Wang, H.; Luo, C.; Zhao, K. Targeting epigenetic machinery: Emerging novel allosteric inhibitors. Pharmacol. Ther. 2019, 204, 107406. [CrossRef]

91. do Amaral Rabello, D.; da Silva Ferreira, V.D.; Berzoti-Coelho, M.G.; Burin, S.M.; Magro, C.L.; da Costa Cacemiro, M.; Simões, B.P.; Saldanha-Araujo, F.; de Castro, F.A.; Pittella-Silva, F. MLL2/KMT2D and MLL3/KMT2C expression correlates with disease progression and response to imatinib mesylate in chronic myeloid leukemia. Cancer Cell Int. 2018, 18, 26. [CrossRef]

92. Chen, Y.; Anastassiadis, K.; Kranz, A.; Stewart, A.F.; Arndt, K.; Waskow, C.; Yokoyama, A.; Jones, K.; Neff, T.; Lee, Y.; et al. MLL2, Not MLL1, Plays a Major Role in Sustaining MLL-Rearranged Acute Myeloid Leukemia. Cancer Cell 2017, 31, 755-770. [CrossRef]

93. Kang, J.; Kim, J.; Kim, K.; Park, J.W.; Cho, H.; Hahm, J.Y.; Chae, Y.; Kim, D.; Kook, H.; Rhee, S.; et al. KDM2B is a histone H3K79 demethylase and induces transcriptional repression via sirtuin-1-mediated chromatin silencing. FASEB J. 2018, 32, 5737-5750. [CrossRef] [PubMed]

94. Nordlund, J.; Syvänen, A.-C. Epigenetics in pediatric acute lymphoblastic leukemia. Semin. Cancer Biol. 2018, 51, 129-138. [CrossRef] [PubMed]

95. Hansen, K.D.; Timp, W.; Bravo, H.C.; Sabunciyan, S.; Langmead, B.; McDonald, O.G.; Wen, B.; Wu, H.; Liu, Y.; Diep, D.; et al. Increased methylation variation in epigenetic domains across cancer types. Nat. Genet. 2011, 43, 768-775. [CrossRef]

96. Easwaran, H.; Tsai, H.-C.; Baylin, S.B. Cancer Epigenetics: Tumor Heterogeneity, Plasticity of Stem-like States, and Drug Resistance. Mol. Cell 2014, 54, 716-727. [CrossRef] [PubMed]

97. Younesian, S.; Shahkarami, S.; Ghaffari, P.; Alizadeh, S.; Mehrasa, R.; Ghavamzadeh, A.; Ghaffari, S.H. DNA hypermethylation of tumor suppressor genes RASSF6 and RASSF10 as independent prognostic factors in adult acute lymphoblastic leukemia. Leuk. Res. 2017, 61, 33-38. [CrossRef]

98. Figueroa, M.E.; Chen, S.-C.; Andersson, A.K.; Phillips, L.A.; Li, Y.; Sotzen, J.; Kundu, M.; Downing, J.R.; Melnick, A.; Mullighan, C.G. Integrated genetic and epigenetic analysis of childhood acute lymphoblastic leukemia. J. Clin. Investig. 2013, 123, 3099-3111. [CrossRef]

99. Dunwell, T.L.; Hesson, L.B.; Pavlova, T.V.; Zabarovska, V.; Kashuba, V.I.; Catchpoole, D.; Chiaramonte, R.; Brini, A.T.; Griffiths, M.; Maher, E.R.; et al. Epigenetic analysis of childhood acute lymphoblastic leukemia. Epigenetics 2009, 4, 185-193. [CrossRef]

100. Nordlund, J.; Bäcklin, C.L.; Wahlberg, P.; Busche, S.; Berglund, E.C.; Eloranta, M.-L.; Flaegstad, T.; Forestier, E.; Frost, B.-M.; Harila-Saari, A.; et al. Genome-wide signatures of differential DNA methylation in pediatric acute lymphoblastic leukemia. Genome Biol. 2013, 14, r105. [CrossRef]

101. Chatterton, Z.; Morenos, L.; Mechinaud, F.; Ashley, D.M.; Craig, J.M.; Sexton-Oates, A.; Halemba, M.S.; Parkinson-Bates, M.; $\mathrm{Ng}$, J.; Morrison, D.; et al. Epigenetic deregulation in pediatric acute lymphoblastic leukemia. Epigenetics 2014, 9, $459-467$. [CrossRef] [PubMed] 
102. Lee, S.-T.; Muench, M.O.; Fomin, M.E.; Xiao, J.; Zhou, M.; de Smith, A.; Martín-Subero, J.I.; Heath, S.; Houseman, E.A.; Roy, R.; et al. Epigenetic remodeling in B-cell acute lymphoblastic leukemia occurs in two tracks and employs embryonic stem cell-like signatures. Nucleic Acids Res. 2015, 43, 2590-2602. [CrossRef] [PubMed]

103. Davidsson, J.; Lilljebjörn, H.; Andersson, A.; Veerla, S.; Heldrup, J.; Behrendtz, M.; Fioretos, T.; Johansson, B. The DNA methylome of pediatric acute lymphoblastic leukemia. Hum. Mol. Genet. 2009, 18, 4054-4065. [CrossRef]

104. Gabriel, A.S.; Lafta, F.M.; Schwalbe, E.C.; Nakjang, S.; Cockell, S.J.; Iliasova, A.; Enshaei, A.; Schwab, C.; Rand, V.; Clifford, S.C.; et al. Epigenetic landscape correlates with genetic subtype but does not predict outcome in childhood acute lymphoblastic leukemia. Epigenetics 2015, 10, 717-726. [CrossRef]

105. Milani, L.; Lundmark, A.; Kiialainen, A.; Nordlund, J.; Flaegstad, T.; Forestier, E.; Heyman, M.; Jonmundsson, G.; Kanerva, J.; Schmiegelow, K.; et al. DNA methylation for subtype classification and prediction of treatment outcome in patients with childhood acute lymphoblastic leukemia. Blood 2010, 115, 1214-1225. [CrossRef] [PubMed]

106. Hogan, L.E.; Meyer, J.A.; Yang, J.; Wang, J.; Wong, N.; Yang, W.; Condos, G.; Hunger, S.P.; Raetz, E.; Saffery, R.; et al. Integrated genomic analysis of relapsed childhood acute lymphoblastic leukemia reveals therapeutic strategies. Blood 2011, 118, 5218-5226. [CrossRef]

107. Rahmani, M.; Talebi, M.; Hagh, M.F.; Feizi, A.A.H.; Solali, S. Aberrant DNA methylation of key genes and Acute Lymphoblastic Leukemia. Biomed. Pharmacother. 2018, 97, 1493-1500. [CrossRef]

108. Wong, I.H.N.; Ng, M.H.L.; Huang, D.P.; Lee, J.C.K. Aberrant p15 promoter methylation in adult and childhood acute leukemias of nearly all morphologic subtypes: Potential prognostic implications. Blood 2000, 95, 1942-1949. [CrossRef]

109. Mai, H.; Liu, X.; Chen, Y.; Li, C.; Cao, L.; Chen, X.; Chen, S.; Liu, G.; Wen, F. Hypermethylation of p15 gene associated with an inferior poor long-term outcome in childhood acute lymphoblastic leukemia. J. Cancer Res. Clin. Oncol. 2016, 142, 497-504. [CrossRef]

110. Shen, L.; Toyota, M.; Kondo, Y.; Obata, T.; Daniel, S.; Pierce, S.; Imai, K.; Kantarjian, H.M.; Issa, J.-P.J.; Garcia-Manero, G. Aberrant DNA methylation of p57KIP2 identifies a cell-cycle regulatory pathway with prognostic impact in adult acute lymphocytic leukemia. Blood 2003, 101, 4131-4136. [CrossRef]

111. Fu, H.; Wu, D.; Zhou, H.; Shen, J. CpG island methylator phenotype and its relationship with prognosis in adult acute leukemia patients. Hematology 2014, 19, 329-337. [CrossRef]

112. Jiang, D.; Hong, Q.; Shen, Y.; Xu, Y.; Zhu, H.; Li, Y.; Xu, C.; Ouyang, G.; Duan, S. The Diagnostic Value of DNA Methylation in Leukemia: A Systematic Review and Meta-Analysis. PLoS ONE 2014, 9, e96822. [CrossRef] [PubMed]

113. Kuang, S.-Q.; Ling, X.; Sanchez-Gonzalez, B.; Yang, H.; Andreeff, M.; Garcia-Manero, G. Differential tumor suppressor properties and transforming growth factor- $\beta$ responsiveness of p57KIP2 in leukemia cells with aberrant p57KIP2 promoter DNA methylation. Oncogene 2007, 26, 1439-1448. [CrossRef]

114. Alexandrova, E.M.; Moll, U.M. Role of p53 family members p73 and p63 in human hematological malignancies. Leuk. Lymphoma 2012, 53, 2116-2129. [CrossRef]

115. Homminga, I.; Pieters, R.; Meijerink, J.P.P. NKL homeobox genes in leukemia. Leukemia 2012, 26, 572-581. [CrossRef] [PubMed]

116. Ueno, S.; Lu, J.; He, J.; Li, A.; Zhang, X.; Ritz, J.; Silberstein, L.E.; Chai, L. Aberrant expression of SALL4 in acute B cell lymphoblastic leukemia: Mechanism, function, and implication for a potential novel therapeutic target. Exp. Hematol. 2014, 42, 307-316. [CrossRef] [PubMed]

117. Javierre, B.M.; Rodriguez-Ubreva, J.; Al-Shahrour, F.; Corominas, M.; Grana, O.; Ciudad, L.; Agirre, X.; Pisano, D.G.; Valencia, A.; Roman-Gomez, J.; et al. Long-Range Epigenetic Silencing Associates with Deregulation of Ikaros Targets in Colorectal Cancer Cells. Mol. Cancer Res. 2011, 9, 1139-1151. [CrossRef]

118. Musialik, E.; Bujko, M.; Wypych, A.; Matysiak, M.; Siedlecki, J.A. TET2 promoter DNA methylation and expression analysis in pediatric B-cell acute lymphoblastic leukemia. Hematol. Rep. 2014, 6, 5333. [CrossRef]

119. Mascarenhas, J.; Roper, N.; Chaurasia, P.; Hoffman, R. Epigenetic abnormalities in myeloproliferative neoplasms: A target for novel therapeutic strategies. Clin. Epigenetics 2011, 2, 197-212. [CrossRef]

120. Gruhn, B.; Naumann, T.; Gruner, D.; Walther, M.; Wittig, S.; Becker, S.; Beck, J.F.; Sonnemann, J. The expression of histone deacetylase 4 is associated with prednisone poor-response in childhood acute lymphoblastic leukemia. Leuk. Res. 2013, 37, 1200-1207. [CrossRef] [PubMed]

121. Mu, Q.; Wang, Y.; Chen, B.; Qian, W.; Meng, H.; Tong, H.; Chen, F.; Ma, Q.; Ni, W.; Chen, S.; et al. High expression of Musashi-2 indicates poor prognosis in adult B-cell acute lymphoblastic leukemia. Leuk. Res. 2013, 37, 922-927. [CrossRef] [PubMed]

122. Mullighan, C.G.; Zhang, J.; Kasper, L.H.; Lerach, S.; Payne-Turner, D.; Phillips, L.A.; Heatley, S.L.; Holmfeldt, L.; Collins-Underwood, J.R.; Ma, J.; et al. CREBBP mutations in relapsed acute lymphoblastic leukaemia. Nature 2011, 471, 235-239. [CrossRef] [PubMed]

123. Mar, B.G.; Bullinger, L.B.; McLean, K.M.; Grauman, P.V.; Harris, M.H.; Stevenson, K.; Neuberg, D.S.; Sinha, A.U.; Sallan, S.E.; Silverman, L.B.; et al. Mutations in epigenetic regulators including SETD2 are gained during relapse in paediatric acute lymphoblastic leukaemia. Nat. Commun. 2014, 5, 3469. [CrossRef] [PubMed]

124. Gocho, Y.; Kiyokawa, N.; Ichikawa, H.; Nakabayashi, K.; Osumi, T.; Ishibashi, T.; Ueno, H.; Terada, K.; Oboki, K.; Sakamoto, H.; et al. A novel recurrent EP300-ZNF384 gene fusion in B-cell precursor acute lymphoblastic leukemia. Leukemia 2015, 29, 2445-2448. [CrossRef] [PubMed]

125. Picaud, S.; Fedorov, O.; Thanasopoulou, A.; Leonards, K.; Jones, K.; Meier, J.; Olzscha, H.; Monteiro, O.; Martin, S.; Philpott, M.; et al. Generation of a Selective Small Molecule Inhibitor of the CBP/p300 Bromodomain for Leukemia Therapy. Cancer Res. 2015, 75, 5106-5119. [CrossRef] [PubMed] 
126. Evans, P.M.; Zhang, W.; Chen, X.; Yang, J.; Bhakat, K.K.; Liu, C. Kruppel-like Factor 4 Is Acetylated by p300 and Regulates Gene Transcription via Modulation of Histone Acetylation. J. Biol. Chem. 2007, 282, 33994-34002. [CrossRef]

127. Moreno, D.A.; Scrideli, C.A.; Cortez, M.A.A.; De Paula Queiroz, R.; Valera, E.T.; Da Silva Silveira, V.; Yunes, J.A.; Brandalise, S.R.; Tone, L.G. research paper: Differential expression of HDAC3, HDAC7 and HDAC9 is associated with prognosis and survival in childhood acute lymphoblastic leukaemia. Br. J. Haematol. 2010, 150, 665-673. [CrossRef] [PubMed]

128. Sonnemann, J.; Gruhn, B.; Wittig, S.; Becker, S.; Beck, J.F. Increased activity of histone deacetylases in childhood acute lymphoblastic leukaemia and acute myeloid leukaemia: Support for histone deacetylase inhibitors as antileukaemic agents. Br. J. Haematol. 2012, 158, 664-666. [CrossRef]

129. de Barrios, O.; Galaras, A.; Trincado, J.L.; Azagra, A.; Collazo, O.; Meler, A.; Agraz-Doblas, A.; Bueno, C.; Ballerini, P.; Cazzaniga, G.; et al. HDAC7 is a major contributor in the pathogenesis of infant $t(4 ; 11)$ proB acute lymphoblastic leukemia. Leukemia 2020. [CrossRef]

130. Vilas-Zornoza, A.; Agirre, X.; Abizanda, G.; Moreno, C.; Segura, V.; De Martino Rodriguez, A.; José-Eneriz, E.S.; Miranda, E.; Martín-Subero, J.I.; Garate, L.; et al. Preclinical activity of LBH589 alone or in combination with chemotherapy in a xenogeneic mouse model of human acute lymphoblastic leukemia. Leukemia 2012, 26, 1517-1526. [CrossRef]

131. Garrido Castro, P.; van Roon, E.H.J.; Pinhanços, S.S.; Trentin, L.; Schneider, P.; Kerstjens, M.; te Kronnie, G.; Heidenreich, O.; Pieters, R.; Stam, R.W. The HDAC inhibitor panobinostat (LBH589) exerts in vivo anti-leukaemic activity against MLL-rearranged acute lymphoblastic leukaemia and involves the RNF20/RNF40/WAC-H2B ubiquitination axis. Leukemia 2018, 32, 323-331. [CrossRef]

132. Thanh Nha Uyen, L.; Amano, Y.; Al-Kzayer, L.F.Y.; Kubota, N.; Kobayashi, J.; Nakazawa, Y.; Koike, K.; Sakashita, K. PCDH17 functions as a common tumor suppressor gene in acute leukemia and its transcriptional downregulation is mediated primarily by aberrant histone acetylation, not DNA methylation. Int. J. Hematol. 2020, 111, 451-462. [CrossRef] [PubMed]

133. Benito, J.M.; Godfrey, L.; Kojima, K.; Hogdal, L.; Wunderlich, M.; Geng, H.; Marzo, I.; Harutyunyan, K.G.; Golfman, L.; North, P.; et al. MLL-Rearranged Acute Lymphoblastic Leukemias Activate BCL-2 through H3K79 Methylation and Are Sensitive to the BCL-2-Specific Antagonist ABT-199. Cell Rep. 2015, 13, 2715-2727. [CrossRef] [PubMed]

134. Krivtsov, A.V.; Armstrong, S.A. MLL translocations, histone modifications and leukaemia stem-cell development. Nat. Rev. Cancer 2007, 7, 823-833. [CrossRef] [PubMed]

135. Erb, M.A.; Scott, T.G.; Li, B.E.; Xie, H.; Paulk, J.; Seo, H.-S.; Souza, A.; Roberts, J.M.; Dastjerdi, S.; Buckley, D.L.; et al. Transcription control by the ENL YEATS domain in acute leukaemia. Nature 2017, 543, 270-274. [CrossRef] [PubMed]

136. Wang, E.; Kawaoka, S.; Yu, M.; Shi, J.; Ni, T.; Yang, W.; Zhu, J.; Roeder, R.G.; Vakoc, C.R. Histone H2B ubiquitin ligase RNF20 is required for MLL-rearranged leukemia. Proc. Natl. Acad. Sci. USA 2013, 110, 3901-3906. [CrossRef] [PubMed]

137. Shema, E.; Tirosh, I.; Aylon, Y.; Huang, J.; Ye, C.; Moskovits, N.; Raver-Shapira, N.; Minsky, N.; Pirngruber, J.; Tarcic, G.; et al. The histone H2B-specific ubiquitin ligase RNF20/hBRE1 acts as a putative tumor suppressor through selective regulation of gene expression. Genes Dev. 2008, 22, 2664-2676. [CrossRef]

138. Geng, H.; Brennan, S.; Milne, T.A.; Chen, W.Y.; Li, Y.; Hurtz, C.; Kweon, S.M.; Zickl, L.; Shojaee, S.; Neuberg, D. Integrative epigenomic analysis identifies biomarkers and therapeutic targets in adult B-acute lymphoblastic leukemia. Cancer Discov. 2012, 2, 1004-1023. [CrossRef] 